\title{
OBSERVATIONS ON MEN PERFORMING A STANDARD AMOUNT OF WORK IN LOW AMBIENT TEMPERATURES
}

\author{
By STEVEN M. HORVATH ${ }^{1}$ AND H. GOLDEN ${ }^{2}$ \\ (From the Armored Medical Research Laboratory, Fort Knox, Kentucky)
}

(Received for publication October 21, 1946)

The activities of the various-armies engaged in this last war have made evident the necessity for adequate information on the responses and reactions of man to the stresses of widely differing environmental conditions. During the past few years great emphasis has been placed upon investigations attempting to delineate the reactions of man to hot environments. Only a very limited number of studies were made in regard to cold weather despite the fact that greater divergences from normal (temperate zone) temperature conditions occur in sub-arctic and arctic areas.

Physiological investigations at these very low temperatures are hampered to some extent by the necessity for excessive amounts of clothing, which makes analysis of the role of the body temperature-regulating apparatus difficult. Even though investigators have been forced to consider only very practical matters, a certain amount of basic information has accrued,-primarily concerning the most adequate means of providing external heat or retaining body heat through the medium of protective clothing. In this report the responses of men working in environments as low as $-46.7^{\circ} \mathrm{C}$. are presented. This complements earlier data (1) on men who sat quietly for long periods of time at similar ambient temperatures.

\section{METHODS}

All experiments were conducted from the months of August through December in the laboratory cold room described in a previous report (1). The environmental temperatures were maintained within $\pm 0.5^{\circ} \mathrm{C}$. Air movement during test periods was practically zero. Exposure of subjects to the environments from $-3.3^{\circ}$ to $-46.7^{\circ} \mathrm{C}$. was made in a random manner. Two to four tests were made on each subject in the various environments except on subject JO., who was not available for ambient temperatures of $-16.1^{\circ}$ and $-20.4^{\circ} \mathrm{C}$. The physical characteristics of the five subjects are presented in Table I. The men were dressed in either of two clothing combinations, ${ }^{3}$ arctic or herringbone twill uni-

\footnotetext{
1 Major, MC, USA.

$2 \mathrm{~T} / 3, \mathrm{MC}, \mathrm{USA}$.
}

forms .3 In general only a single test was made on each subject during the day and that between 9 and 12 o'clock. The occasional 2- and 3-hour walking periods were conducted in the afternoon. The test procedure was as follows: each subject rested for 1 hour in a cool room $\left(24^{\circ}\right.$ C., 50 per cent $\mathrm{RH}$ ), donned a thermocouple harness,

TABLE I

Physical characteristics of subjects

\begin{tabular}{c|c|c|c|c}
\hline \hline Subject & Age & Height & Weight & Surface area \\
\cline { 5 - 5 } & & $c m$. & kgm. & $M^{2}$. \\
Ve. & 19 & 172 & 60.4 & 1.69 \\
Jo. & 20 & 169 & 73.5 & 1.83 \\
Gl. & 19 & 164 & 62.1 & 1.66 \\
Ca. & 21 & 159 & 53.4 & 1.53 \\
Kl. & 19 & 175 & 70.8 & 1.83 \\
\hline
\end{tabular}

and was dressed in one of the uniforms. Rectal and skin temperatures were taken and the subject, entering the cold room, stepped onto the moving belt of the treadmill. At the completion of the hour work period, the man left the cold room and did not re-enter until another experiment on the following day.

The treadmill in use had a walking surface provided by a roughened rubber belt sliding on a rigidly supported maple slipway. All tests were conducted at a speed of 3.0 miles per hour and a grade of 3.3 per cent. Skin temperatures were measured at 10-minute intervals at five or ten points with copper constantan thermocouples, and the mean skin temperature was calculated by the procedure suggested by Hardy and DuBois (2). Rectal temperatures were obtained either by calibrated clinical

\footnotetext{
3 Arctic uniform:

Drawers, wool, 50/50

Undershirt, wool, 50/50

Trousers, field, pile

Trousers, field, cotton, O.D. (sateen 9 oz.)

Parka, field, cotton, O.D. (sateen 9 oz.)

Parka, pile

Shoes, arctic, felt

Socks, wool, ski (2 pairs)

Socks, wool, cushion sole (1 pair)

Mittens, insert, trigger finger, M-1943

Mittens, shell, trigger finger, M-1943.

Herringbone twill uniform:

Suit, work, one piece herringbone twill

Shorts, cotton

Socks, wool, ski (1 pair)

Shoes, arctic, felt.
} 
thermomters or by indwelling rectal thermocouples. Expired air was collected in compensated gasometers and analyses of aliquot gas samples collected over mercury were performed in duplicate using the Haldane machine. These machines were checked by daily analysis of outdoor air. Calculations for the oxygen consumption, respiratory quotient, and caloric expenditure were made in the usual manner. Inspired air was at the same temperature as the environmental. During the work periods, the respiratory exchange was determined after 10 and 45 minutes of walking. Collections of expired air were made for 10-minute periods. Heart rate by palpation was obtained on four occasions, before work and at 20,40 , and 55 minutes from the onset of walking.

\section{RESULTS}

The subjects were given preliminary training on the treadmill for a period of 12 days. Control studies were made at $24^{\circ} \mathrm{C}$. on the 2 days prior to the first cold room exposure and again on the 2 days following the last low temperature day. No after-stimulating effect of cold was noted, the results being very similar to the pre-cold tests. Consequently all four tests at $24^{\circ} \mathrm{C}$. were averaged to give the single control value in the tables. The data obtained on the men when dressed in the arctic uniform and working in the following eight low temperatures, $-3.3^{\circ},-16.1^{\circ},-20.4^{\circ}$, $24.8^{\circ},-27.2^{\circ},-31.0^{\circ},-37.2^{\circ}$, and $-46.7^{\circ} \mathrm{C}$., are to be found in Tables II and III. Additional information is shown graphically in Figures 1 to 4 .

Regardless of the type of clothing worn, the energy expenditure for the standard work load was always higher in the cold environments, - the average increase being approximately 12 per cent. The greater caloric expenditure was not due to

TABLE II

Metabolic observations on 5 men dressed in arctic clothing and walking on a treadmill at 3.0 M.P.H. and a 3.3 per cent grade during their first hour of exposure to the described environmental temperatures

\begin{tabular}{|c|c|c|c|c|c|c|c|c|c|c|c|c|}
\hline \multirow[t]{2}{*}{$\begin{array}{c}\text { Environmental } \\
\text { temperature }\end{array}$} & \multicolumn{2}{|c|}{ Ventilation } & \multicolumn{2}{|c|}{$\begin{array}{l}\text { Respiratory } \\
\text { quotient }\end{array}$} & \multicolumn{2}{|c|}{$\begin{array}{c}\text { Oxygen } \\
\text { consumption }\end{array}$} & \multicolumn{6}{|c|}{ Heat production } \\
\hline & $\begin{array}{l}\text { l. per } \\
\text { min. }\end{array}$ & $\underset{\text { per cent }}{\Delta}$ & & $\stackrel{\Delta}{\Delta e r c e n t}$ & $\begin{array}{l}\text { l. per } \\
\text { min. }\end{array}$ & $\underset{\text { per cent }}{\Delta}$ & $\begin{array}{l}\text { cal. per } \\
\text { hr. }\end{array}$ & $\underset{\text { per cent }}{\Delta}$ & $\begin{array}{c}\text { cal. per } \\
M^{2} \text { per } \\
\text { hr. }\end{array}$ & $\underset{\text { per cent }}{\Delta}$ & $\begin{array}{c}\text { cal. per } \\
\text { kgm. per } \\
\text { hr. }\end{array}$ & $\underset{\text { per cent }}{\Delta}$ \\
\hline Basal $^{*}+24.0^{\circ} \mathrm{C}$. & 24.9 & & .85 & & 1.18 & & 345 & & 207 & & 5.7 & \\
\hline $\begin{array}{l}-3.3^{\circ} \mathrm{C} . \\
-16.1^{\circ} \mathrm{C} . \\
-20.4^{\circ} \mathrm{C} . \\
-24.8^{\circ} \mathrm{C} . \\
-27.2^{\circ} \mathrm{C} . \\
-31.0^{\circ} \mathrm{C} . \\
-37.2^{\circ} \mathrm{C} . \\
-46.7^{\circ} \mathrm{C} .\end{array}$ & $\begin{array}{l}27.3 \\
27.0 \\
26.8 \\
26.4 \\
28.1 \\
28.0 \\
27.1 \\
27.4\end{array}$ & $\begin{array}{r}9.6 \\
8.4 \\
7.6 \\
6.0 \\
12.8 \\
12.4 \\
8.8 \\
10.0\end{array}$ & $\begin{array}{l}.86 \\
.90 \\
.82 \\
.84 \\
.85 \\
.86 \\
.86 \\
.86\end{array}$ & $\begin{array}{r}1.2 \\
5.9 \\
-3.5 \\
-1.2 \\
0.0 \\
1.2 \\
1.2 \\
1.2\end{array}$ & $\begin{array}{l}1.25 \\
1.31 \\
1.33 \\
1.33 \\
1.38 \\
1.31 \\
1.32 \\
1.32\end{array}$ & $\begin{array}{r}5.9 \\
11.0 \\
12.7 \\
12.7 \\
16.9 \\
11.0 \\
11.9 \\
11.9\end{array}$ & $\begin{array}{l}366 \\
387 \\
384 \\
388 \\
401 \\
384 \\
386 \\
387\end{array}$ & $\begin{array}{r}6.1 \\
12.2 \\
11.3 \\
12.5 \\
16.2 \\
11.3 \\
11.9 \\
12.2\end{array}$ & $\begin{array}{l}215 \\
218 \\
221 \\
226 \\
235 \\
222 \\
222 \\
226\end{array}$ & $\begin{array}{r}3.9 \\
5.3 \\
6.8 \\
9.2 \\
13.5 \\
7.2 \\
7.2 \\
9.2\end{array}$ & $\begin{array}{l}5.8 \\
5.8 \\
5.9 \\
6.1 \\
6.3 \\
5.9 \\
5.9 \\
6.1\end{array}$ & $\begin{array}{r}1.8 \\
1.8 \\
3.5 \\
7.0 \\
10.5 \\
3.5 \\
3.5 \\
7.0\end{array}$ \\
\hline
\end{tabular}

* Wore herringbone twill uniform.

TABLE III

Temperatures $\left({ }^{\circ} \mathrm{C}\right.$.) and heart rate of 5 subjects dressed in arctic clothing going into recorded temperatures and immediately starting to walk on the treadmill at 3.0 M.P.H. at a 3.3 per cent grade

\begin{tabular}{|c|c|c|c|c|c|c|c|c|c|c|c|}
\hline \multirow{2}{*}{$\begin{array}{c}\text { Environmental } \\
\text { temperature }\end{array}$} & \multicolumn{3}{|c|}{ Rectal temperature } & \multicolumn{3}{|c|}{ Mean skin temperature } & \multicolumn{3}{|c|}{ Toe temperature } & \multicolumn{2}{|c|}{ Heart rate per min. } \\
\hline & Before & After & $\Delta$ & Before & After & $\Delta$ & Before & After & $\Delta$ & Range & Average \\
\hline Basal* $^{*}+24.0^{\circ} \mathrm{C}$. & 37.3 & 37.9 & 0.6 & & & & & & & $85-110$ & 103 \\
\hline $\begin{array}{l}-3.3^{\circ} \mathrm{C} . \\
-16.1^{\circ} \mathrm{C} . \\
-20.4^{\circ} \mathrm{C} . \\
-24.8^{\circ} \mathrm{C} . \\
-27.2^{\circ} \mathrm{C} . \\
-31.0^{\circ} \mathrm{C} . \\
-37.2^{\circ} \mathrm{C} . \\
-46.7^{\circ} \mathrm{C} .\end{array}$ & $\begin{array}{l}37.2 \\
36.8 \\
37.2 \\
37.3 \\
37.3 \\
37.1 \\
37.2 \\
37.2\end{array}$ & $\begin{array}{l}37.8 \\
37.5 \\
37.9 \\
38.1 \\
37.7 \\
37.7 \\
38.0 \\
38.2\end{array}$ & $\begin{array}{l}0.6 \\
0.7 \\
0.7 \\
0.8 \\
0.4 \\
0.6 \\
0.8 \\
1.0\end{array}$ & $\begin{array}{l}33.1 \\
31.5 \\
32.5 \\
33.5 \\
33.0 \\
33.0 \\
32.9 \\
33.2\end{array}$ & $\begin{array}{l}33.7 \\
33.4 \\
31.1 \\
30.0 \\
32.2 \\
31.2 \\
31.4 \\
29.4\end{array}$ & $\begin{array}{r}0.6 \\
1.9 \\
-1.4 \\
-3.5 \\
-0.8 \\
-1.8 \\
-1.5 \\
-3.8\end{array}$ & $\begin{array}{l}21.6 \\
22.8 \\
26.9 \\
30.5 \\
26.7 \\
26.1 \\
28.8 \\
21.7\end{array}$ & $\begin{array}{l}34.7 \\
33.9 \\
32.6 \\
32.8 \\
34.4 \\
31.1 \\
33.3 \\
30.7\end{array}$ & $\begin{array}{r}13.1 \\
11.1 \\
5.7 \\
2.3 \\
7.7 \\
5.0 \\
4.5 \\
9.0\end{array}$ & $\begin{array}{r}102-118 \\
102-105 \\
81-102 \\
82-114 \\
88-110 \\
78-118 \\
72-126 \\
100-110\end{array}$ & $\begin{array}{r}110 \\
104 \\
95 \\
103 \\
102 \\
108 \\
106 \\
107\end{array}$ \\
\hline
\end{tabular}

* Wore herringbone twill uniform. 
the additional clothing worn, since the weight of the herringbone twill uniforms was the same at $24^{\circ} \mathrm{C}$. as at the lower temperatures. For some inexplicable reason the highest values were always obtained at the envinronmental temperature of $27.2^{\circ} \mathrm{C}$. The smallest increase in caloric output was observed in the least cold environment, $3.3^{\circ} \mathrm{C}$.; in fact, when the herringbone twill uniform was worn, no differences from the control values were noted. However, in environmental temperatures above this, the increases were roughly similar for both garment assemblies. Cold appeared to provide a small but definite stimulus to the metabolic processes.

The average oxygen consumption of all the subjects at the different environmental temperatures is plotted in Figure 1, and, in Figure 2, a smiliar plot is presented for subject JO. These latter data, unfortunately not for every ambient temperature, are presented because his oxygen consumption at $24^{\circ} \mathrm{C}$. was the same as the average for the group. Furthermore, JO, showed the greatest change of the five men at the ambient temperature of $-3.3^{\circ} \mathrm{C}$.
The ventilation rate was also raised but in approximately the same proportion as the oxygen consumption. The frequency of breathing was not increased, the larger ventilation being compensated by adjustment in depth of respiration. Barcroft and Verzar (3) noted some irregular gasping in the breathing pattern of their subjects exposed to low temperatures, but no abnormalities were noted in this study, even at the lowest environmental temperature, $-46.7^{\circ} \mathrm{C}$. The respiratory quotient exhibited no consistent change, being higher at some environments, lower at others, and the same as the control $\left(24^{\circ} \mathrm{C}\right.$. $)$ in the remainder.

The heart rate during work showed no significant changes with varying ambient temperatures, and the amount of clothing worn made no significant difference.

The changes in skin and rectal temperatures were quite different with the two types of clothing worn and will be discussed separately in the following sections.

Arctic clothing. This clothing combination has an insulative value between 4 and $5 \mathrm{Clo}$. and was

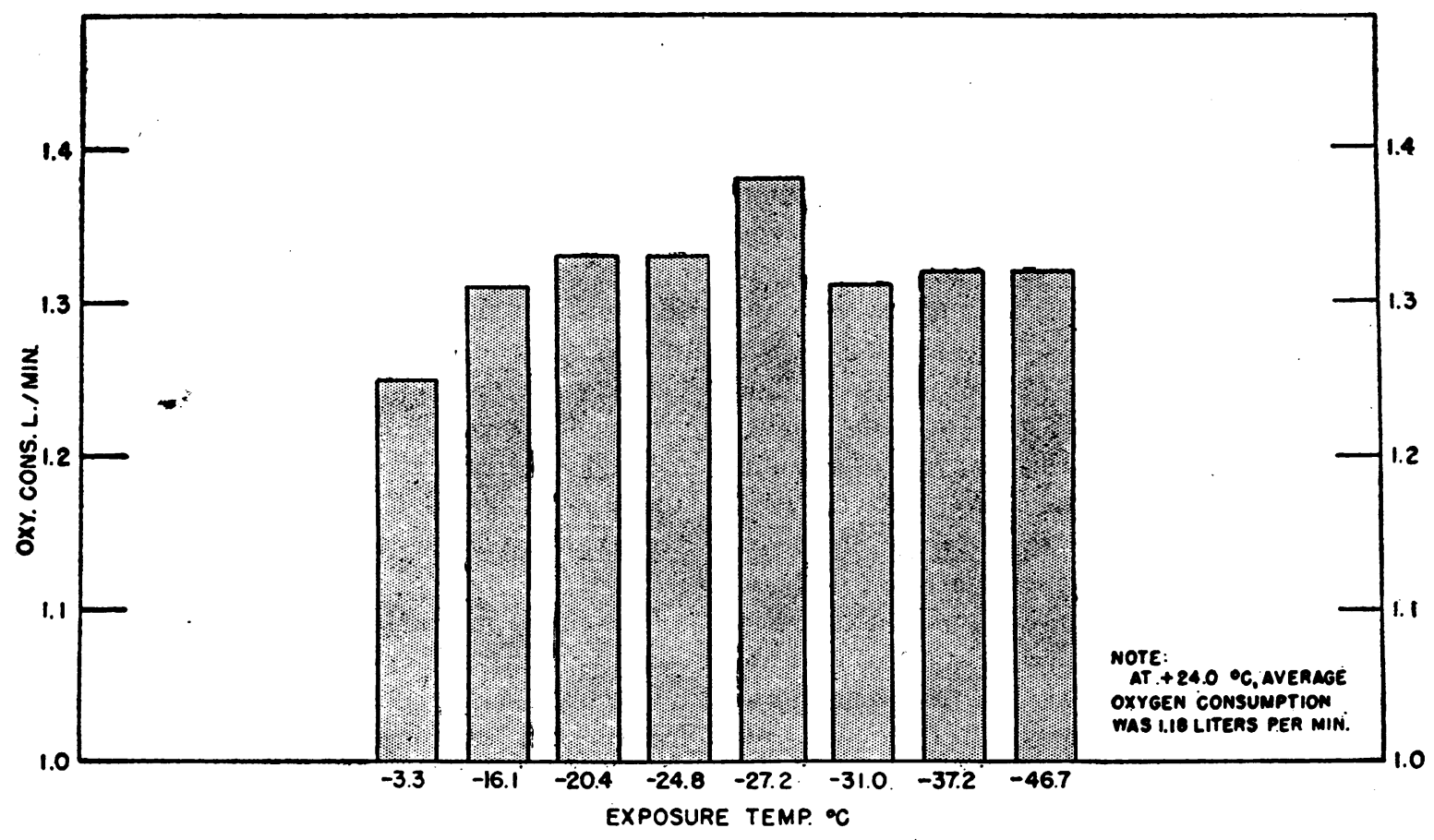

Fig. 1. Oxygen Consumption of Five (5) Subjects Dressed in Arctic Clothing and Walking on Treadmill at 3.0 M.P.H. and a 3.3 Per Cent Grade During Their First Hour of Exposure to the Indicated TEMPERATURES 


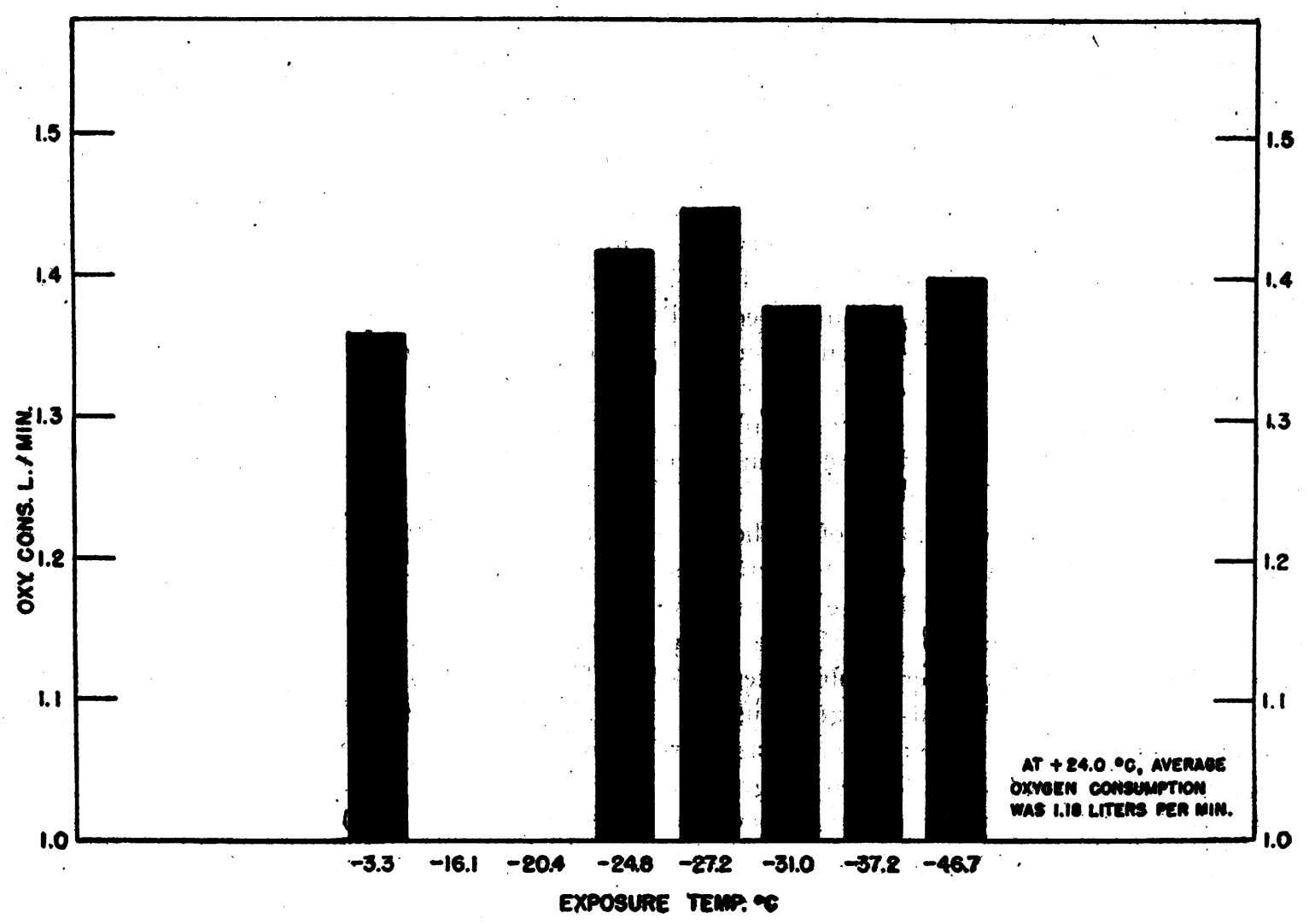

Fig. 2. Oxygen Consumption of One Subject (JO.) Dressed in Arctic Clothing and Walking on Treadmill at 3.0 M.P.H. and a 3.3 Per Cent Grade During His First Hour of Exposure to the Indicated TEMPERATURES

worn completely buttoned during the walk. It was thought that the increased energy expenditure might be due to the weight of this outfit, 10 kilograms, but subsequent experiments with the herringbone twill issue and one experiment on a subject completely nude except for socks and shoes at $-20.4^{\circ} \mathrm{C}$. indicated that the higher caloric output was primarily due to the stimulus of the low ambient temperature. Rectal temperatures were elevated to the same degree in normal and very cold environments. Only at $-46.7^{\circ} \mathrm{C}$. was the increase significantly higher, $0.4^{\circ} \mathrm{C}$. above the control, which was probably related to the greater vasoconstriction occurring at this low ambient temperature. Toe temperatures rose in all cases (Figure 3 and Table III), but the increases were somewhat erratic due to the variations in initial toe temperatures. Again the final level was approximately the same at all environments except at $-47.7^{\circ} \mathrm{C}$.- - a finding which bears out the suggestion of a more generalized vasoconstriction at this ambient temperature.

The explanation for finding higher final toe temperatures than mean skin temperatures is not available. It may have been due to a vasodilation being present in the extremities or to local friction effects. When subjects walk in hot environments, toe and foot temperatures as high as $3^{\circ}$ to $5^{\circ} \mathrm{C}$. above mean skin temperatures are frequently observed and could be explained as a consequence of friction.

The initial mean skin temperatures were quite constant. In the two least severe environments, final mean skin temperatures showed an actual increase, but beginning with $-20.4^{\circ} \mathrm{C}$. decreases were always observed. The lowest value was found at the lowest ambient temperature. Storage values, calculated according to Burton's (4) formula, followed a pattern similar to the changes in mean skin temperatures primarily because the 


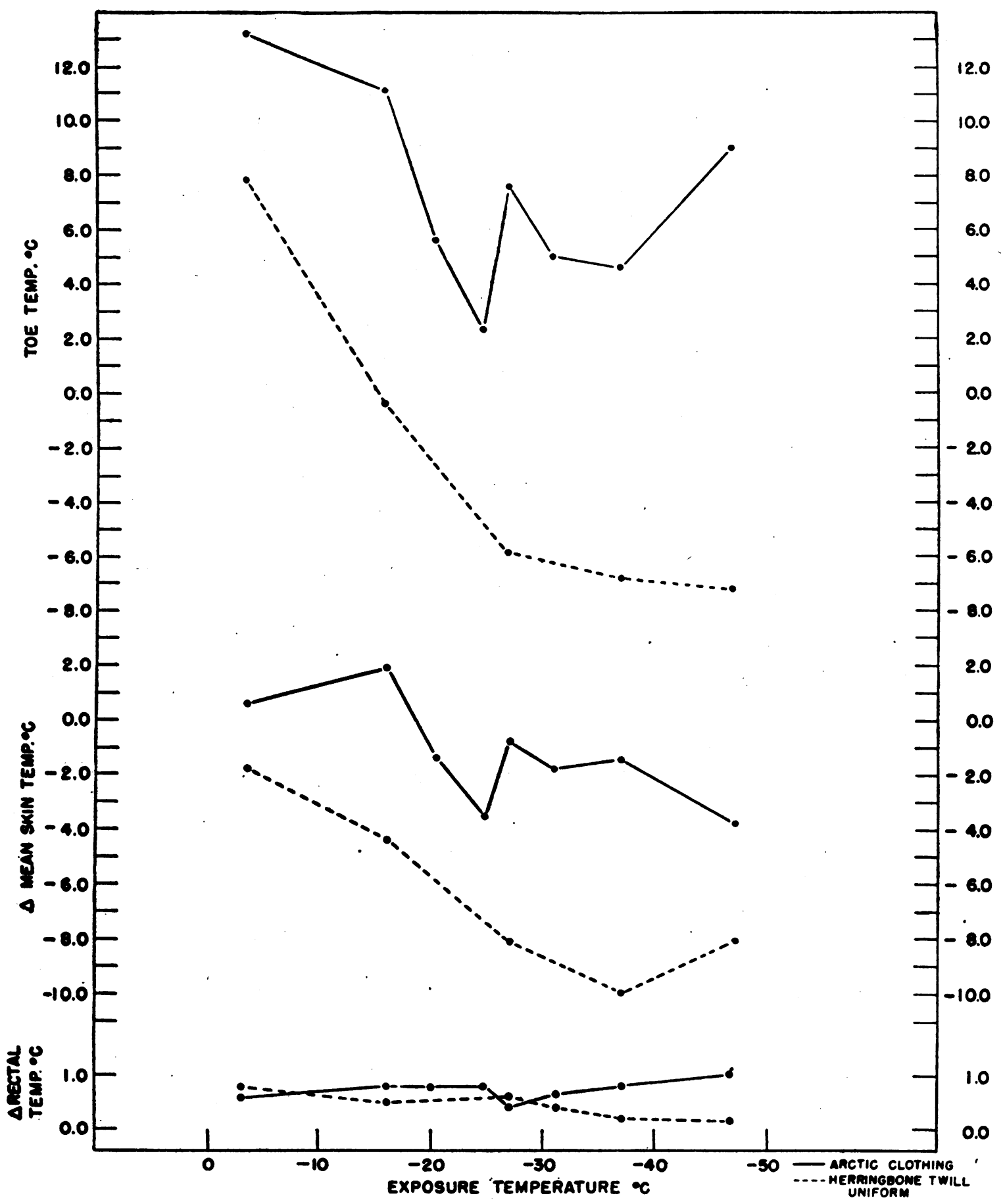

Fig. 3. Influence of Environmental Temperature and Clothing on the Mean Changes in the Temperature of Certain Parts Immediately before and after a 1-Hour Walk on the Treadmill at 3.0 M.P.H. at a 3.3 Per Cent Grade

Data are the average of five subjects. 
Mean values for heat debts * incurred during work

\begin{tabular}{|c|c|c|c|c|c|c|c|c|}
\hline \multirow{2}{*}{ Uniform } & \multicolumn{8}{|c|}{ Heat debt in cal. per $\mathbf{M}^{2}$. per hr. } \\
\hline & $\begin{array}{l}\text { At } \\
-3.3^{\circ} \mathrm{C} .\end{array}$ & $\underset{-16.1^{\circ} \mathrm{C} .}{\mathrm{At}}$ & $\begin{array}{c}\text { At } \\
-20.4^{\circ} \mathrm{C} .\end{array}$ & $\begin{array}{l}\text { At } \\
-24.8^{\circ} \mathrm{C}\end{array}$ & $\begin{array}{l}\text { At } \\
-27.2^{\circ} \mathrm{C}\end{array}$ & $\begin{array}{l}\mathrm{At} \\
-31.0^{\circ} \mathrm{C}\end{array}$ & $\begin{array}{l}\text { At } \\
-37.2^{\circ} \mathrm{C}\end{array}$ & $\begin{array}{l}\text { At } \\
-46.7^{\circ} \mathrm{C} .\end{array}$ \\
\hline $\begin{array}{l}\text { Arctic } \\
\text { Herringbone twill }\end{array}$ & $\begin{array}{r}-18.5 \\
4.0\end{array}$ & $\begin{array}{r}-34.1 \\
35.4\end{array}$ & 0.0 & 19.9 & $\begin{array}{r}0.0 \\
75.5\end{array}$ & 6.2 & $\begin{array}{r}-1.0 \\
100.2\end{array}$ & $\begin{array}{l}18.6 \\
80.0\end{array}$ \\
\hline
\end{tabular}

* A negative value indicates that heat was stored.

rectal temperature exhibited so little change from one environment to another.

Herringbone Twill. This clothing assembly weighs approximately 4 kilograms and has an insulative value between 1 and 2 Clo. There was no change in average caloric output at $-3.3^{\circ} \mathrm{C}$. compared to the control environment of $24^{\circ} \mathrm{C}$. (Table IV). However, as the environmental temperature decreased the energy expenditure increased, showing a maximum rise of 12 per cent at an ambient of $-46.7^{\circ} \mathrm{C}$. The stimulative effect of cold was also reflected in the greater losses of body heat (see Table above). No appreciable debt was incurred at $-3.3^{\circ} \mathrm{C}$. , but at $-37.2^{\circ} \mathrm{C}$., a debt of 100 cal. per $\mathrm{M}^{2}$. was noted. There appeared to be a positive correlation between heat debt and-ambient temperature at least up to $-37.2^{\circ} \mathrm{C}$. These data on storage are reflections of the inability of the subjects to raise their rectal and mean skin temperatures despite the production of almost 400 calories per hour (Table V). The toe temperatures were increased only at $-3.3^{\circ} \mathrm{C}$. At all other environments the toe temperatures fell despite the exercise (Figure $3)$, the final values being lower the colder the environment.

TABLE IV

Metabolic observations on 5 men dressed in herringbone twill coveralls walking on a treadmill at 3.O M.P.H. and a 3.3 per cent grade during their first hour of exposure to the described environmental temperatures

\begin{tabular}{|c|c|c|c|c|c|c|c|c|c|c|c|c|}
\hline $\begin{array}{c}\text { Environmental } \\
\text { temperature }\end{array}$ & \multicolumn{2}{|c|}{ Ventilation } & \multicolumn{2}{|c|}{$\begin{array}{l}\text { Respiratory } \\
\text { quotient }\end{array}$} & \multicolumn{2}{|c|}{$\begin{array}{c}\text { Oxygen } \\
\text { consumption }\end{array}$} & \multicolumn{6}{|c|}{ Heat production } \\
\hline & $\begin{array}{l}\text { l. per } \\
\text { min. }\end{array}$ & $\mid \begin{array}{c}\Delta \\
\text { per cent }\end{array}$ & & $\underset{\text { per cent }}{\Delta}$ & $\begin{array}{l}\text { l. per } \\
\text { min. }\end{array}$ & $\underset{\operatorname{per} c e n t}{\Delta}$ & $\begin{array}{c}\text { cal. per } \\
\text { hr. }\end{array}$ & $\underset{\text { per cent }}{\Delta}$ & $\begin{array}{c}\text { cal. per } \\
M^{2} \text {. per } \\
\text { hr. }\end{array}$ & $\underset{\text { per cent }}{\Delta}$ & $\begin{array}{l}\text { cal. per } \\
\text { kgm. per } \\
\text { hr. }\end{array}$ & $\underset{\operatorname{per} c e n t}{\Delta}$ \\
\hline Basal $+24.0^{\circ} \mathrm{C}$. & 24.9 & & .85 & & 1.18 & & 345 & & 207 & & 5.7 & \\
\hline $\begin{array}{l}-3.3^{\circ} \mathrm{C} . \\
-16.1^{\circ} \mathrm{C} . \\
-27.2^{\circ} \mathrm{C} . \\
-37.2^{\circ} \mathrm{C} . \\
-46.7^{\circ} \mathrm{C} .\end{array}$ & $\begin{array}{l}25.8 \\
26.9 \\
25.2 \\
27.2 \\
26.8\end{array}$ & $\begin{array}{l}3.6 \\
8.0 \\
1.2 \\
9.2 \\
7.6\end{array}$ & $\begin{array}{l}.88 \\
.89 \\
.83 \\
.87 \\
.86\end{array}$ & $\begin{array}{r}3.0 \\
4.7 \\
-2.4 \\
2.4 \\
1.2\end{array}$ & $\begin{array}{l}1.18 \\
1.29 \\
1.27 \\
1.29 \\
1.32\end{array}$ & $\begin{array}{r}0.0 \\
9.3 \\
7.6 \\
9.3 \\
11.9\end{array}$ & $\begin{array}{l}346 \\
379 \\
361 \\
377 \\
388\end{array}$ & $\begin{array}{r}0.3 \\
9.8 \\
4.6 \\
9.3 \\
12.5\end{array}$ & $\begin{array}{l}202 \\
224 \\
219 \\
223 \\
227\end{array}$ & $\begin{array}{r}-2.4 \\
8.2 \\
5.8 \\
7.7 \\
9.7\end{array}$ & $\begin{array}{l}5.4 \\
5.9 \\
6.0 \\
6.0 \\
6.1\end{array}$ & $\begin{array}{r}-5.3 \\
3.5 \\
5.3 \\
5.3 \\
7.0\end{array}$ \\
\hline
\end{tabular}

TABLE V

Temperatures $\left({ }^{\circ} C\right.$.) and heart rate of 5 subjects dressed in herringbone twill coveralls going into recorded temperatures walking on treadmill at 3.0 M.P.H. and at 3.3 per cent grade during their first hour of exposure to the described environmental temperatures

\begin{tabular}{|c|c|c|c|c|c|c|c|c|c|c|c|}
\hline \multirow{2}{*}{$\begin{array}{c}\text { Environ- } \\
\text { mental } \\
\text { tempera- } \\
\text { tures }\end{array}$} & \multicolumn{3}{|c|}{ Rectal temperature } & \multicolumn{3}{|c|}{ Mean skin temperature } & \multicolumn{3}{|c|}{ Toe temperature } & \multicolumn{2}{|c|}{ Heart rate per min. } \\
\hline & Before & After & $\Delta$ & Before & After & $\Delta$ & Before & After & $\Delta$ & Range & Average \\
\hline $\begin{array}{l}{ }^{\circ} C . \\
-\quad 3.3 \\
-16.1 \\
-27.2 \\
-37.2 \\
-46.7\end{array}$ & $\begin{array}{l}37.2 \\
37.6 \\
37.5 \\
37.6 \\
37.6\end{array}$ & $\begin{array}{l}37.9 \\
38.1 \\
38.1 \\
37.9 \\
37.8\end{array}$ & $\begin{array}{l}0.7 \\
0.5 \\
0.6 \\
0.3 \\
0.2\end{array}$ & $\begin{array}{l}32.8 \\
33.6 \\
34.0 \\
34.0 \\
33.2\end{array}$ & $\begin{array}{l}31.0 \\
29.2 \\
25.9 \\
24.0 \\
25.1\end{array}$ & $\begin{array}{l}-1.8 \\
-4.4 \\
-8.1 \\
-10.0 \\
-8.1\end{array}$ & $\begin{array}{l}26.5 \\
32.8 \\
33.6 \\
31.0 \\
30.7\end{array}$ & $\begin{array}{l}34.4 \\
32.5 \\
27.7 \\
24.4 \\
23.5\end{array}$ & $\begin{array}{r}7.9 \\
-0.3 \\
-5.9 \\
-6.6 \\
-7.2\end{array}$ & $\begin{array}{r}93-114 \\
88-114 \\
82-116 \\
102-116 \\
88-116\end{array}$ & $\begin{array}{r}104 \\
104 \\
99 \\
109 \\
104\end{array}$ \\
\hline
\end{tabular}




\section{DISCUSSION}

There is no evidence that man is seriously handicapped in his ability to work in cold environments. As suggested by the increased energy expenditure for the same work output, the net efficiency for grade walking by these subjects was slightly reduced by the cold. However, additional work loads must be studied before a final statement regarding changes in efficiency of performance can be made. Adolph and Molnar (5) stated that "when the air was too cold, extra heat was produced above that which was a by-product of the work." The caloric output of their subjects at an environmental temperature of $37^{\circ}$ to $39^{\circ} \mathrm{F}$. was 299 cal. per M. ${ }^{2}$ per hr. in contrast to 190 at an ambient temperature of $40^{\circ}$ to $46^{\circ} \mathrm{F}$. Such a degree of stimulation was not observed in our very lightly clothed subjects at environmental temperatures of $-46.7^{\circ} \mathrm{C}$. $\left(-52.1^{\circ} \mathrm{F}\right.$.). Their subjects sometimes shivered while working-an observation never noted in this study. The subjects in this study never felt more than slightly chilly and in general were fairly comfortable.

In the group of experiments at $-20.4^{\circ}$ and $-37.2^{\circ} \mathrm{C}$., during which men walked for periods up to 3 hours, no additional changes were observed above those recorded for the 1-hour tests. Caloric expenditures appeared to decrease slightly, rectal temperatures rose approximately $0.1^{\circ} \mathrm{C}$. per hour, and the mean skin temperatures were similar to those obtained at the end of the first hour. A balance in the heat exchange appeared to have been reached.

Heart rates were not significantly different at normally comfortable and extremely cold environments regardless of the amount of clothing worn. Previous reports (5) have suggested some correlation between the pulse rates of working men and lowered environmental temperatures. The differences between the results of this study and that of Adolph and Molnar (5) might be explained on the basis of clothing, since their subjects were nearly nude, but a disparity in clothing insulation of $2 \mathrm{Clo}$. would not be likely to compensate for a temperature differential of nearly $90^{\circ} \mathrm{F}$. However, the effects of cold on sensory phenomena and cold tolerance may be greatly influenced by clothing and so affect the physiological measurements under consideration. Additional studies are clearly needed.

The major differences observed in the responses of the lightly and heavily clothed working subjects were in their rectal and skin temperatures. The rectal temperature rise in the cold was maintained at the same or even slightly higher level in working men wearing arctic suits as in a comfortable environment. Lightly dressed subjects had difficulty in reaching or maintaining this level except in the least cold ambient temperature. The colder the environment, the smaller was the elevation of the rectal temperature. The mean skin temperature exhibited a similar pattern in that large decreases were observed for the lightly clothed individuals with relatively small falls or actual increases for the heavily clothed.

In Figure 4, are plotted the data obtained on the mean skin and toe temperatures of a subject during one of these work periods at three of the lowest environmental temperatures employed. These changes in mean skin temperature with the wearing of the two clothing issues are typical. The major portion of the decrease occurred during the first 10 minutes of work and was maintained at a relatively constant level thereafter. Therefore, the major portion of the heat debt accumulated by the body occurred not only in a short period of time but also relatively early in the exposure. Measurements of the caloric expenditure of the subjects during these first 10 minutes indicated that the rate was the same then as during later portions of the work period. A similar type of response was noted in sitting subjects (1) where the greatest body heat loss also took place in the first phase of the exposure. This initial contribution appeared to be of vital importance in maintaining the working balance of heat exchanges in men exposed to low temperature. The significance of rapid loss of body heat in the regulation of body temperature was not evident from these studies.

The toe temperatures of the same subject (Figure 4) are interesting in that they not only showed the general pattern of response, but they reached the lowest level attained by any of the subjects during work. When the arctic uniform was being worn, an initial fall was noted which in almost every case then proceeded to rise, reaching stable 
levels within a half hour after the beginning of the work period. This was not true when the lighter clothing assembly was worn, under which condition the toe temperature continued to go down after an initial fall. The rate of decrease diminished considerably as the experiment continued.
The general beneficial effects of greater total insulation are obvious from these data.

The caloric expenditure for a given amount of work was slightly greater in the cold regardless of the degree of insulation provided by the clothing. The difference in the weights of the two

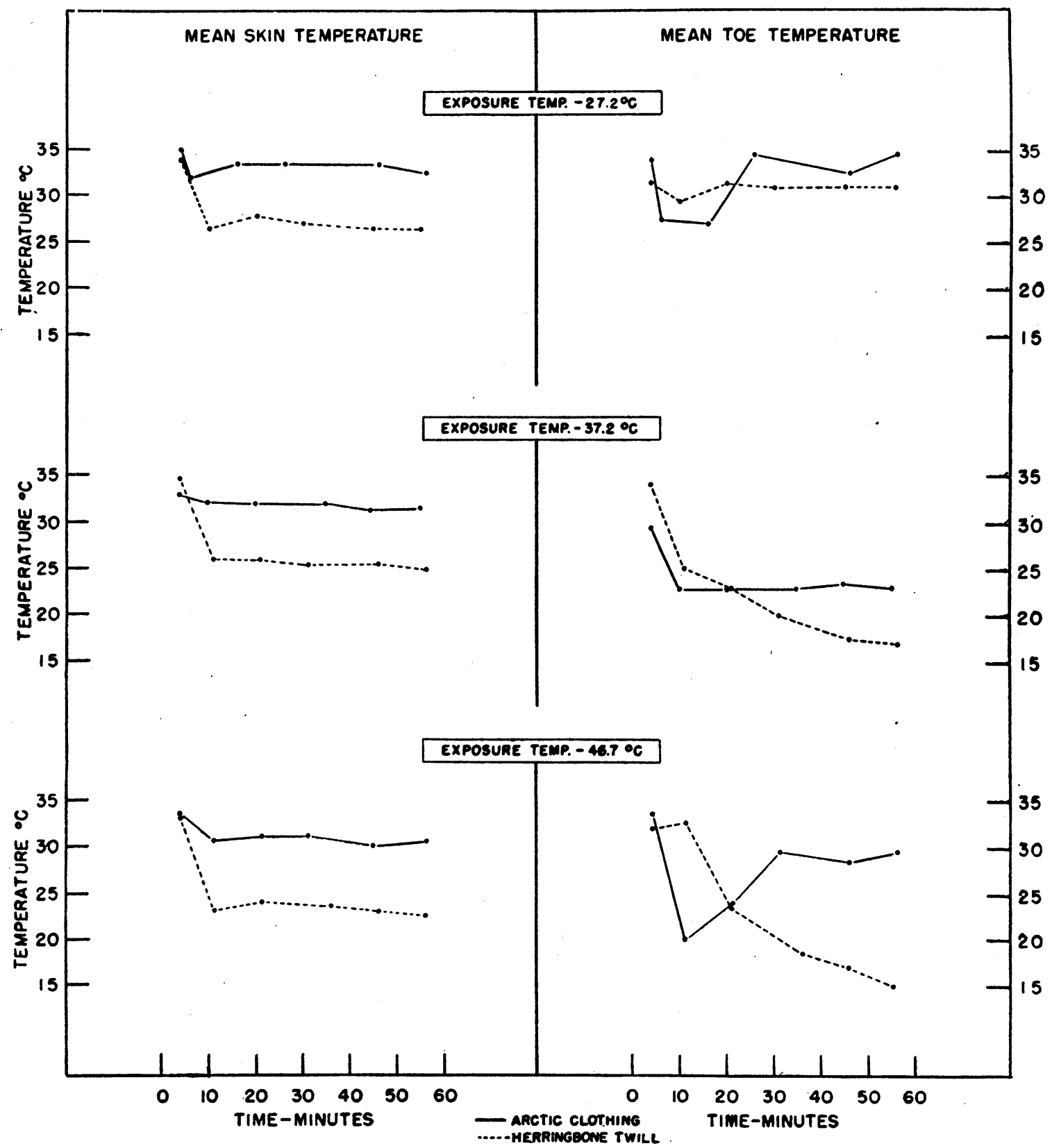

Fig. 4. Comparison of the Rate and Degree of Change of Mean Skin and Toe Temperatures in a Subject During a 1-Hour Walk Dressed in Either a Full Arctic Uniform or a Pair of Herringbone Twill Coveralls 
garment assemblies resulted in only minor variations in the extent of the stimulation to metabolic processes. The diminution of mechanical efficiency in these subjects was of small magnitude. It might be explained as being due to the increased cost of respiratory effort, increased viscosity of cold muscles, or any number of small factors that inhibit the development of maximum skill and ease of work performance.

Men dressed in the arctic uniform can strike a balance of heat exchange while working at a caloric expenditure of around 350 calories per hour in ambient temperatures as low as $-46.7^{\circ} \mathrm{C}$. However, this is only a partial answer to the adequacy of this type of clothing, since the accumulation of perspiration in the fabrics will alter a man's ability to maintain a balanced heat exchange, especially when he stops work. With very light dress, heat balances are not so readily attained at very low ambient temperatures. The degree of stress may be roughly estimated from the heat debt accrued. Caution in the use of these figures must be exercised, since the calculation of heat debt as presently performed may not be valid in cold environments.

No evidences of acclimatization to cold were found in this study. The intermittent nature of the exposures and the relatively short periods of time spent in the cold probably prevented the development of any such effect.

\section{SUMMARY}

1. Five subjects, wearing light and heavy clothing, walked at a standard rate of speed and grade of climb on a motor-driven treadmill in comfortable and very cold environments.

2. The energy expenditure for the standard work was increased by some 10 per cent in the lower ambient temperatures. This stimulation appeared to be independent of the amount of clothing worn. Ability to work was not significantly impaired even at ambient temperatures as low as $-46.7^{\circ} \mathrm{C}$., although there was a slight diminution of mechanical efficiency at certain of the environments.

3. The loss of body heat was greater with a light weight clothing and the magnitude of the loss appeared to be directly related to the ambient temperature. Heat debts were less but quite variable when heavy clothing was worn. In all cases, the heat debts were accumulated in the early portion of exposure to the cold environment.

\section{ACKNOWLEDGMENT}

The authors wish to exress their appreciation of the excellent cooperation of the enlisted men who voluntarily served as subjects and to Mr. James Gregg, M/Sgt. Walter Kupchick, M/Sgt. John Gray, T/Sgt. H. Bloom, T/3 J. Wagar, Mrs. James M. Nelson, and Mrs. Steven M. Horvath, for their assistance in conducting the experiments and the analysis of the data.

\section{BIBLIOGRAPHY}

1. Horvath, S. M., Golden, H., and Wagar, J., Some observations on men sitting quietly in extreme cold. J. Clin. Invest., 1946, 25, 709.

2. Hardy, J. D., and DuBois, E. F., The technic of measuring radiation and convection. J. Nutrition, 1938, 15, 461.

3. Barcroft, J., and Verzar, F., The effect of exposure to cold on the pulse rate and respiration of man. J. Physiol., 1931, 71, 373.

4. Burton, A. C., Human calorimetry. The average temperature of the tissues of the body. J. Nutrition, 1935, 9, 261.

5. Adolph, E. F., and Molnar, G. W., Exchanges of heat and tolerances to cold in men exposed to outdoor weather. Amer. J. Physiol., 1946, 146, 507.

6. Wolf, S., and Hardy, J. D., Studies on pain: Observations on pain due to local cooling and on factors involved in the "cold pressor" test. J. Clin. Invest., 1941, 20, 521. 